\title{
Military Expenditure and Migration in Europe
}

\author{
Joanne Evans* \\ University of Surrey
}

\author{
Eleftherios Goulas \\ University of Patras
}

July 30, 2006

\author{
Paul Levine \\ University of Surrey
}

\begin{abstract}
The enlargement of the EU has implications for the national defence requirements and therefore national defence policy of European nations. In light of the freedom of movement of citizens between member states it is appropriate to consider the implications of a country's military expenditure for it's macroeconomy and specifically on the flows of migration between member states. Traditionally income differentials, employment levels and relative standards of living are all factors that influence an individual's decision to migrate. To this list we add the level of military expenditure. Migration from a panel of sixteen CEECs to Germany between 1995 and 2002 is found to be the result of the level of military expenditure of the source country and the host country in conjunction with factors consistent with standard theoretical predictions.
\end{abstract}

JEL Classification: C33, F22, J61

Keywords: European enlargement, migration, military expenditure.

\footnotetext{
${ }^{*}$ Corresponding Author
} 


\section{Contents}

1 Introduction 1

2 European Security and Defence $\quad 3$

3 Military Expenditure and Growth 5

4 The Model and Data $\quad 7$

5 Results of Dynamic Panel Estimation 9

6 Policy Implications - Military Expenditure and Migration 13

7 Conclusions $\quad 14$ 


\section{Introduction}

The expansion of the EU has to an extent changed the way member (and non-member) states need to address questions of national defence and security. The protection afforded to EU members should imply that the sums of military expenditure necessary at a national level are reduced. However General Moschini (chairman of the EU Military Committee) recently observed ${ }^{1}$ that for the time being however, "each nation wants to keep, for political reasons, a complete structure of defence, in order to be strategically autonomous, sometimes according to old-fashioned territorial concepts." Hence the current low efficiency of national defence expenditure and the duplication of structures at national level which should be avoided. His colleague Nick Witney (European Defence Agency) ${ }^{2}$ agreed that there was evidence of too much duplication of effort across Europe, even though Europeans accounted for a quarter of the world military expenditure the combined EU R\&D budget was five times less than the amount spent by the $\mathrm{US}^{3}$.

Efficient national defence spending is necessary and is undertaken at the expense of expenditure in other areas of the economy. Thus the further expansion of the EU and the freedom of movement for its people has implications for the migration flows. Spending a relatively high proportion of national GDP on national defence is likely to cause migration with far reaching defence and other implications for the source and host countries within the EU. There are many reasons that prompt migration. Traditionally theory suggests that these include wages and employment levels.

Given the impact of military expenditure on growth and freedom of movement of population of EU member states we test to see whether the ratio of military expenditure to GDP in the host and the source country has an impact on migration and find that the military expenditure of both the source and the host nation have an impact on migration. Military expenditure of the source country has a positive impact on migration, whereas military expenditure of the foreign country has a negative impact.

\footnotetext{
${ }^{1}$ At a press conference held on 10 February 2006 following the WEU conference on 7 th and 8th of February 2006.

${ }^{2}$ At the same press conference.

${ }^{3}$ However the level of national military expenditure has often been a proxy for the prospect of conflict. That is, the amount of military expenditure will increase as the prospect of conflict. For example Turkey has high levels of military expenditure as a result of the conflict with Greece over Cyprus.
} 
We construct a panel data set of countries that are either members of the EU, acceding countries, candidate countries or potential candidates. This is done in order to consider the substantial migration flows from sixteen CEECs to Germany between 1995 and 2002 and the factors affecting these flows. As well as those factors traditionally found to impact movement, we consider the effect of military expenditure through its indirect effect on the standard of living. This research is based on the work of McCormick et al (2002), who explain potential migration through income differentials and employment rates in the host and source countries as well as military expenditure.

The profiles of the 16 CEEC's included in our sample are diverse. The average unemployment rates of the countries range between 4 and $15 \%$ and new entrants are higher. GDP per capita is typically high for EU members and relatively low for acceding countries, while the ratio of military expenditure to GDP ranges widely between $.77 \%$ and $5 \%$. The new issues to consider regarding the implications of such military expenditure with the freedom of movement by nationals between EU member states. There is a trade off and the opportunity cost of high levels of military expenditure is great therefore it may be timely for member states to reconsider their military expenditure budgets.

There are many factors that influence the rate of growth of a country and in turn the standard of living of its population. Allocation to the military budget for example, implies foregoing allocation to the non-military budget and subsequently a trade-off between military budgets and social expenditure (Brauer, 2002). Therefore, high or increased military expenditure implies the existence of an opportunity cost between social expenditure and quality of living. For as long as governments tax their populations to finance the military sector, they reduce the private sector's resources and are likely to affect consumption and investment. Little has been said in the literature about the influence of military expenditure and indeed the link between the military expenditure of the home country on the migration flows. Most of the literature in this area deals with military expenditure and growth. However it is likely that the relationship is more complex then previously suggested in the literature as military expenditure may be a proxy for conflict. That is it is likely to be high and/ or increased in regions where the prospect of conflict is high or increasing.

The paper proceeds with an outline of the European Security and Defence arrange- 
ments in section 2 and a review of the literature in section 3. A discussion of the model used, its specification and the characteristics of the data set used in the estimations are presented in section 4 . The results of the dynamic panel estimations are presented in section 5 with the policy implications of these results discussed in section 6 . Section 7 concludes.

\section{European Security and Defence}

One of the great political objectives of Europe is to maintain its stability with a solid security framework. The development of the framework goes back to the start of European integration when the Common Foreign and Security Policy (CFSP) was added to the political agenda. The parliamentary Assembly of Western European Union (WEU) was Europe's first Security and Defence Assembly founded in $1954^{4}$ when the 1948 Brussels treaty was modified. The Treaty contains an unconditional mutual defence clause (Article V) and links WEU member countries with NATO (Article IV). Its role has developed and was included in 1991 in the new provisions on security policy in the Treaty of Maastricht.

The WEU comprises 400 parliamentarians from the national parliaments of 37 European countries, including all EU member states (including the ten signatory states of the modified Brussels Treaty) and the European members of NATO as well as Russia, Ukraine and the Balkan states. There are different voting and participation rights depending upon the category of membership. Full members ${ }^{5}$ have full voting rights. Affiliate members ${ }^{6}$ are entitled to vote in committee and in plenary on the substantive texts (recommendations) that are submitted to the plenary session. WEU observer countries and representatives from other EU member states whose governments have full rights in the European Security and Defence Policy (ESDP $)^{7}$ but no status in WEU are also entitled to vote in committee. Affiliate associate partner delegates ${ }^{8}$ take part in all Assembly activities including

\footnotetext{
${ }^{4}$ The first session was held in 1955.

${ }^{5}$ Belgium, France, Germany, Greece, Italy, Luxembourg, Portugal, Spain, the Netherlands and the UK

${ }^{6}$ Affiliate members include the Czech Republic, Estonia, Hungary, Lativa, Lithuania, Poland, Slovak Republic, Slovenia

${ }^{7}$ ESDP is a move from nation based defence towards a security position of the European Union.

${ }^{8}$ Associate Members include Iceland, Norway and Turkey; Affiliate Associate Members include Bulgaria, Romania. Permanent Observers include Austria, Denmark, Finland, Ireland and Sweden, Affiliate Permanent Observers Cyprus and Malta and Affiliate Associate Partner is Croatia.
} 
committee meetings and plenary sessions but do not vote on the texts and may speak in plenary debates. Permanent guests ${ }^{9}$ and special guests ${ }^{10}$ countries may also speak in plenary debates.

The EU defence arrangements developed with the agreement between the UK and France $^{11}$ that the EU should have the capacity for autonomous action, backed up by credible military forces, the means to decide to use them and a readiness to do so in order to respond to international crises. The aim was to not duplicate, but to complement NATO structures. EU-NATO relations and cooperations were functioning well on the basis of the Berlin plus agreements. EU crisis management capabilities accrued from 1999 initially with targets of a 60000 strong EU crisis reaction force. The intention was to create a separable but not separate forces that could be made available for European led crisis response operations other than collective defence ${ }^{12}$. The force would be able to mount and lead crisis management operations in response to international crises where the Alliance as a whole is not engaged. Decisions relating to crisis management tasks with military or defence implications are taken in accordance with Article 23 of the Treaty on EU however member states retain the right to decide if and when their national forces are deployed. The 1992 St 'Petersberg tasks' define the scope of crisis-management operations to which the EU governments wished to respond and continues to guide crisis management missions of the EU. Including humanitarian and rescue missions, peacekeeping and missions of combat forces in crisis management including missions undertaken in Yugoslavia, Albania, Croatia, Macedonia and Serbia.

Dialogue continues as to how best to preserve national parliaments' security ${ }^{13}$ and pool them with the complementary competences of the European Parliament in the field of civil crisis management. The Protocol on the Role of National Parliaments in the EU

\footnotetext{
${ }^{9}$ Russian Federation, Ukraine

${ }^{10}$ Albania, Bosnia and Herzegovina, FYROM (Macedonia), Serbia and Montenegro

${ }^{11}$ St Malo Summit, December 1998

${ }^{12}$ The European Security Strategy requires joint forces of a high quality and high readiness group with a comprehensive basket of capabilities to which all member states could contribute according to their resources. There is also a need to create EU command and control structures as well as non-military components.

${ }^{13}$ Proposal for European Security and Defence Assembly (ESDA) to monitor the activities of the EU security bodies from the perspective of national parliamentarians (Lisbon Initiative 2000)is one possible option.
} 
is appended to the Constitutional Treaty currently in the consultation phase. The role of the WEU as the acting inter-parliamentary platform for the ESDP on the basis of the parliamentary instruments for which the WEU legal framework makes provision will be largely obsolete with the advent of the European Constitutional Treaty ${ }^{14}$. The Treaty is intended to promote confidence in the EU provision for its members and therefore encourage economic growth.

\section{Military Expenditure and Growth}

The question of the impact of military expenditure on economic growth has exercised academics for over thirty years. Benoit (1973) found a positive effect of the share of military expenditure on growth but others since have not been able to confirm this result. Military expenditure has not been found to be an important determinant of growth ${ }^{15}$. Recently Dunne et al (2005) highlights why the literature presents conflicting views as to the impact of military expenditure on growth and suggests that the often used Feder-Ram model should be avoided and that the augmented Solow and Barro models hold better prospects.

A variety of recent studies across a spectrum of countries including some of those considered in our analysis found that military expenditure does in fact affect economic growth. The impact on long and short term growth varies between countries. Yildirim et al (2005) found that military expenditure enhanced economic growth in Middle Eastern countries and Turkey during the 1990's. In the case of Cyprus, Kollias et al(2004) find a presence of bidirectional instantaneous causality between defence spending and growth. Karagol and Palaz (2004) identify a long run equilibrium relationship between GNP and defence expenditures and a unidirectional causality between variables from defence expenditure to economic growth in the case of Turkey. Where a shock to defence spending saw GNP decrease. Defence expenditures and external debt for Turkey are co-integrated. Karagol (2005) find evidence of long and short run unidirectional causality running from defence

\footnotetext{
${ }^{14}$ The Constitutional Treaty includes a solidarity clause giving member states the possibility to request aid and assistance from the other EU countries in the event of a terrorist attack. There is also a non-binding mutual defence clause.

${ }^{15}$ The growth literature has typically focused on long term growth of output rather than the short term effects.
} 
expenditures to external debt but not vice versa ${ }^{16}$ And in more recent work Karagol (2006) finds that the defence expenditures have a positive effect on external debt stock. Impulse response functions of GNP to defence expenditures tended to hike within two years ahead and dipped sharply by two years and thereafter continued at a positive level.

In Europe, there is evidence that military expenditures are often used as a variable of economic adjustment and that inertia effects are important. Coulomb and Fontanel(2005) find that since 1990 French military expenditures are more of an economic burden than a driving force. This may in part be due to their procurement procedure. Dunne et al (forthcoming) show how concentration depends on willingness of producers to import their military needs and on relative size of external market of non-producers. They find substantial gains to producers from cooperation in procurement process and small gains to non-producers involved in regional arms race. Also arms export control that the limit level of technology that can be exported to non-producers distribute these cooperative gains from producers to non-producers.

In other parts of the world Yildirim and Ocal (2006) find a mutual causal relationship between the military expenditures of India and Pakistan ${ }^{17}$. Military expenditure does not Granger cause economic growth in Pakistan, however there is causality from military expenditure to economic growth in India. Military expenditure is found to hinder economic growth in India in the long run but has a growth promoting effect in the short run. In Taiwan, Lee and Chang (2006) find evidence of the existence of a long run equilibrium co-integrated relationship between defence expenditure, GDP, labour and capital stock. A bidirectional causal relationship exists in the long run between defence spending and GDP in Taiwan implying that increasing defence spending in Taiwan is an effective means to boost overall economic performance and the improved economy leads to further defence expenditure. However defence spending is a major means of adjusting for disequilibria that occur in the system.

The military burden does indeed have a positive impact on the share of external debt to GDP in small industrializing countries (Dunne et al, 2004a). However, there is no evidence that the military burden had any impact on the evolution of debt in Argentina and Brazil but some evidence that military burden tended to increase debt in Chile (Dunne et al,

\footnotetext{
${ }^{16}$ For a data set of the period $1955-2000$.

${ }^{17}$ The data set used was $1949-2003$.
} 
2004b). Chile was the least affected by acute financial crisis resulting from debt problems although its relative levels of debt were as high or higher. Suggesting that the military burden maybe important in determining debt in countries but it is only of significance when it is not swamped by other macroeconomic and international factors. The arms race effect was found to affect countries long run growth. Ihori (2004) finds the ratio of security spending to GDP increases with economic growth if defence technology has a fixed benefit.

Even in the US, Cuaresma and Reitschuler (2004) found evidence of the level dependent effect of military expenditure on GDP growth. The positive externality effect of defence spending prevails for relatively lower levels of defence spending and reverts its influence for higher levels.

A large literature then exists on the impact of military expenditure on growth with evidence that there are short-term positive demand effects, but adverse long-term effects. Standard migration theory would then suggest indirect effect on migration through changes in relative income. Little work has been done in this area, however, on CEEC's and to the best of our knowledge no study exists on the direct effect of military expenditure on migration flows. This the focus for the rest of the paper.

\section{The Model and Data}

We model the long-term relationship between the stock of migrants, GDP per capita, the unemployment rate, and a measure of military expenditure as a proportion of GDP. We assume (as McCormick et al., 2002) that the rate of change in the stock of migrants or the share of the population which already resides in the foreign countries is determined by the economic variables such as, the difference in the log of per capita incomes and the employment rates in the foreign and the home countries.

In this study we attempt to identify the factors that trigger migration to Germany and especially focus on the role that military expenditures might play in the decision to migrate. We focus on the impact that the prospect of conflict has as the main factor prompting national military expenditure. The model presented here relies on the work of Hatton (1995) and McCormick et al. (2002) and is based on the premise that migration is an investment in human capital, the returns to which are determined by expectations of future income. These expectations of income in the country of destination are conditioned 
by the perceived opportunity to find a job in its labour market (McCormick et al., 2002). We augment the standard migration model by considering military expenditures in the home and the foreign countries as possible determinants of migration.

Theory suggests that migration is determined by the income differential between the host and the source country, as well as the employment rates in the host and the source countries. The income differential between the host and the source country, and the conditions in the labour market of the host country described by its employment rate, would be expected to have a positive impact on migration, while the conditions in the labour market of the source country would intuitively be expected to have a negative impact. We anticipate that military expenditures in the source countries will boost migration signifying a positive migration-military expenditure relationship. On the other hand, military expenditures of the host country are expected to manifest a negative nexus with the potential to migrate. Therefore, our model is of the following form:

$$
\begin{aligned}
(\Delta S M)_{i, t} & =\delta_{0}+\delta_{1}(\Delta S M)_{i, t-1}+\delta_{2} \Delta \ln \left(E_{F}\right)_{i, t}+\delta_{3} \Delta \ln \left(E_{H}\right)_{i, t}+\delta_{4} \Delta \ln \left(\frac{Y_{F}}{Y_{H}}\right)_{i, t} \\
& +\delta_{5} \ln \left(E_{F}\right)_{i, t-1}+\delta_{6} \ln \left(E_{H}\right)_{i, t-1}+\delta_{7} \ln \left(\frac{Y_{F}}{Y_{H}}\right)_{i, t-1}+\delta_{8}\left(\frac{M E_{H}}{G D P_{H}}\right)_{i, t-1} \\
& +\delta_{9}\left(\frac{M E_{F}}{G D P_{F}}\right)_{i, t-1}+\varepsilon_{i, t}
\end{aligned}
$$

where the annual change in the ratio of the stock of migrants to the source population is, $\Delta S M_{i, t}$. The differential in real wages, which is proxied by the annual change in the difference of the GDP per capita at current prices in US dollars between the host and the source country, $\Delta \ln \left(\frac{Y_{F}}{Y_{H}}\right)_{i, t}$. Employment opportunities as proxied by the annual change in the employment rate (1-unemployment rate) in the host country, $\Delta \ln \left(E_{F}\right)_{i, t}$, and the source country, $\Delta \ln \left(E_{H}\right)_{i, t}$. The value of the difference of the GDP per capita between the host and the source country lagged one year, $\ln \left(\frac{Y_{F}}{Y_{H}}\right)_{i, t-1}$. The value of the employment rate lagged one year in the host country, $\ln \left(E_{F}\right)_{i, t-1}$, and the source country, $\ln \left(E_{H}\right)_{i, t-1}$. The lagged by one year value of military expenditures over GDP at current prices in US dollars for the source country, $\left(\frac{M E_{H}}{G D P_{H}}\right)_{i, t-1}$, and the host country, $\left(\frac{M E_{F}}{G D P_{F}}\right)_{i, t-1}$. And $\delta$ are unknown constant parameters to be estimated, $F$ denotes the foreign or host country, $H$ the home or source country, and $\varepsilon$ is an unobserved spherical disturbance term. 
This model is able to capture both short and long run effects as it includes variables specified both in the level, lagged and others, which are first differenced. The variables specified in the level determine a dynamic relationship between the stock of migrants and the income and employment variables in the long run, whereas the rate of change variables determine the response of migration to short term fluctuations of the explanatory variables.

We use aggregated data for 16 Central and Eastern European countries (CEECs) including Latvia, Lithuania, Poland, Hungary, Estonia, Cyprus, Czech Republic, Malta, Slovenia, Slovakia, Turkey, Serbia and Montenegro, Romania, Bulgaria, Croatia and the former Yugoslavian Republic of Macedonia for the period 1995-2002. The countries chosen are either EU members or in the case of Bulgaria and Romania are acceding. ${ }^{18}$ Candidate countries include Croatia, Macedonia and Turkey. While Serbia is one of the potential candidate countries. Our panel consists of $i$ countries over a period of $t$ years. The total number of observations included in our sample is 128 .

We use a variety of data sources to construct the necessary variables. Data on GDP per capita at current prices in millions US dollars and total population come from the National Accounts Main Aggregates Database maintained by the United Nations (http://www.un.org/). Data on the stock of migrants for the main Central and Eastern European countries included in our sample were available on the Migration Information Source (Global Data Center) (http://www.migrationinformation.org/). Yearly data on unemployment rates come from the LABORSTA database maintained by the International Labour Organization (ILO) (http://laborsta.ilo.org/). Finally, data on military expenditures for the receiving and the home countries were provided by the Stockholm International Peace Research Institute (SIPRI) (http://www.sipri.org/).

The average values for the main aggregates by country are set out in Table 1 .

\section{Results of Dynamic Panel Estimation}

The parameters of equation (1) are estimated by applying the Arellano and Bond (1991) Generalized Method of Moments (GMM) dynamic panel technique. The actual estimation is based on the first-differences of all variables included in the model, which results in a new disturbance term exhibiting, by construction, first-order autocorrelation. However,

\footnotetext{
${ }^{18}$ In May 2006 the Commission approved the monitoring report.
} 
to ensure unbiased and consistent estimates it is important to ensure that the differenced equations are free from second or higher order autocorrelation. The statistical adequacy of the model is therefore established when two conditions are met; firstly the generated residuals do not exhibit second-order autocorrelation, this property is checked by the use of the $m_{2}$ statistic of Arellano and Bond (1991), and secondly that the over-identifying restrictions are not rejected as measured by the Sargan (1958) test. Sargan (1958) tests the validity of the instrument set based on the correlation between the instruments and the residuals. Based on a Chi-squared distribution, our results (presented in Table 2) suggest that instruments and residuals are not correlated. The Sargan test fails to reject the null hypothesis that the over identifying restrictions are valid. The growth of the military burden is influenced by economics and strategic factors. External war has a negative impact on growth of the military burden. This is because there is an increase in the military expenditure post conflict to replace equipment and better prepare for future conflict.

The estimation process is carried out in two stages and from the first stage inferences can be drawn about the coefficients and the second for inferences on model specification. Initially we test the factors that traditionally are thought to influence the levels of migration. The results of regression 1 in Table 2 show that those variables traditionally thought to influence migration; the employment opportunities in both the source and the host country, as well as the ratio of GDP per capita all do significantly influence migration.

The second regression confirms that not only are the traditional factors that are thought to affect migration significant, as expected, but also the level of military expenditure of the source country is significant. However the results of regression 3 suggest that military expenditure in the host country is not significant; that is the impact of host military expenditure without the consideration of source military expenditure is not significant in the decision to migrate. The results of regression 4 are more interesting. If we look at the results of regression 4 , we note that the military expenditure of both the host and the source countries when considered together has a significant impact on migration. This suggests that those who migrate may do so because their standard of living is affected by the level of military expenditure as a proportion of GDP consider where they will go and will be unlikely to choose a host country that has a higher level of military 
expenditure as a proportion of its GDP than the source country. Indeed the size of the impact of military expenditure on the decision to migrate is larger for the host country's expenditure than that for the source country. ${ }^{19}$

The hypothesis test results presented at the bottom of Table 2 confirms that the impact of miliary expenditure in the host and the source countries are important factors affecting migration. The null hypothesis that military expenditure of the home and the host countries has no impact is rejected as $\delta_{8}$ and $\delta_{9}$ are not statistically equal to zero (implying that they both have some impact), nor are they statistically equal to each other.

To determine the impact of the factors in the host and the source country the Wilcoxon Test is used to test the hypothesis that the various factors in each country have identical median values and identical distributions. The results presented in Table 3 indicate that the populations from which the samples have been taken do not in fact have identical median values and identical distributions as the null hypothesis is rejected in every instance with the p-value of zero in every instance, that is the associated factors between the source and host country are not of equal impact on the decision to migrate.

Our results indicate that an increase in military expenditure has triggered migration flows to Germany as aggregate consumption has decreased due to the increased military expenditure which is financed by public funds. This result is of special importance for Turkey. Annually, Turkey is obliged to incur high military costs due to its strategic position in Eastern Europe, which is driven by NATO commitments, fears of Islamic fundamentalism, the desire to suppress Kurdish militants and disagreements with Greece (Brauer, 2001). In contrast, member states' whose military expenditure did not differ significantly from the expenditure of other Eastern European countries during the communist era will not be as affected.

Our results show that based on the current amount of military expenditure of the countries in the sample if that military expenditure of the source country has a $2 \%$ impact on the stock of migrants. Our results imply that on average if military expenditure of the 16 source countries considered in our analysis were increase by $50 \%$ then there would be an average increase in the migrant stock per population of $3 \%$. If however military

\footnotetext{
${ }^{19}$ Note that there is only one host country (Germany) in this analysis. A formal test that migrants choose their destination on the basis of the military expenditure in that country requires a major extension of this study to incorporate several host nations. This would be a fruitful area for future research.
} 
expenditure of these countries were to be cut by $50 \%$ there would be a fall in the stock of migrants of $1 \%$. This implies that on average there would be no migrant stock of people wanting to migrate to Germany in 12 out of the 16 countries we considered if military expenditure of these countries were to be cut in half. Only Croatia (3.62\%), Macedonia (1.35\%), Serbia and Montenegro (5.64\%) and Turkey $(2 \%)$ would have a migrant stock wanting to move to Germany. On average whilst these countries have amongst the highest average rates of unemployment, they are not the top 4 on the list in Table 1 . In terms of GDP per capita these countries although amongst the lowest, do not exhibit the lowest percentage in the sample. In terms of military expenditure as a proportion of GDP; Croatia has the highest at 5\%, Turkey $4.6 \%$, Macedonia $2.93 \%$. Others over $2 \%$ including Romania (2.65\%) and Cyprus (2.63\%) have low migrant stocks per population therefore the reason for high migrant stock of these four Croatia, Macedonia, Serbia and Turkey (after a 50\% reduction in military expenditure) maybe due to the populations perceived threat of conflict. Thus the results on average reflect the unrest of the countries (decrease in the quality of living due to fear of war) rather than the impact that military expenditure has on GDP and growth (standards of living).

We have focused on the impact of a change in the source countries military expenditure, we turn now to consider the impact of a change in the military expenditure of the host country (Germany). Our results show that if the host country was to increase its military expenditure by $50 \%$ the stock of migrants would fall by $105 \%$, that is, no longer would it be a destination of choice for migrants from CEEC's but also there would be Germans wanting to leave Germany to live elsewhere. Conversely, if Germany, the host country were to reduce it's military expenditure by $50 \%$ on average the migration stock would double. That is, assuming the status quo remains our results indicate that the migrant stock will be reduced by $70 \%$. When military expenditure is halved so too is the impact on the migrant stock and at that level of military expenditure as a proportion of GDP only $35 \%$ of people remain in the stock - implying that $35 \%$ of people wishing to migrate has been reduced by $35 \%$. Half the migrant stock has been turned away from migrating to the host country. This implies that the decision to migrate is calculated and migrants do not want to move from one country to another when they perceive their standard of living to be compromised. Instead migrants will only want to go when the perceived prospects 
are improved.

\section{Policy Implications - Military Expenditure and Migration}

The expansion of the EU to date ${ }^{20}$ has prompted (or is likely to prompt) migration from accession countries to those in the West to be more intense due to the agreement of free movement of workers among the countries of the European Union (Drinkwater et al., 2002). As a consequence, a deterioration of living standards of unskilled workers in conjunction with job displacement and wage losses triggered by the inflow of low-cost labour and the de-localization of plants from the West to the East is feared (Boeri and Brucker, 2001). Bauer and Zimmermann (1999) predict long run migration rates to potentially be between 2 - 3 percent of the population of the source country. However, these migration rates are likely to fall as living standards in the Central and Eastern European countries (CEECs) improve (Drinkwater et al, 2002).

As the EU is set to expand further in $2007^{21}$ and then again in 2015 with the likely inclusion of Turkey and the former Yugoslavia if they meet with the accession criteria of the EU. Their inclusion and the new freedom of movement that it brings to their populations are set to have an impact on the population movement between member states. Therefore our findings have implications for how member and non-member states should think about their domestic policy. The freedom of movement afforded to people of member states means that movement of skilled and unskilled labour in search of an improved standard of living is likely.

Rights and privileges afforded to EU members mean that the amount of national military expenditure that is necessary has changed and this has implications for alternatives that the money can be used for and therefore perceived standards of living.

Clearly our results suggest that national military expenditure has an impact on migration stock. Therefore public policy needs to account for this fact with appropriate measures. To help determine what might be the appropriate policy option; changes in

\footnotetext{
${ }^{20}$ On the 1st of May in 2004 Latvia, Lithuania, Poland, Hungary, Estonia, Cyprus, Czech Republic, Malta, Slovenia and Slovakian Republic joined the European Union.

${ }^{21}$ Bulgaria and Romania are recommended to receive candidate status with the view to joining the EU on the 1st of January 2007.
} 
national or EU military expenditure, measures to deal with migration flows or some combination of these. We have considered what would happen on average to the migration stock under a number of alternative scenarios ${ }^{22}$. Our results suggest that a favourable policy option is likely to be to encourage a reduction in national military expenditure. A significant driver of this will hinge on the development and evolution of the ESDP and the provision of EU protection which inspires member (and non-member) confidence $^{23}$. For candidate countries of our sample some short term migration constraints so as to avoid a large exodus of skilled and unskilled labour around the time of accession which will drain the source economy and flood the host countries.

\section{Conclusions}

The expansion of the EU has implications for the economies of both the accession countries as well as those established EU members. The agreement of free movement of workers among the countries of the EU is set to influence the labour markets in both the host and the source countries. In this paper we analyzed the determinants of international migration from 16 CEEC's to Germany between 1995 and 2002. During this period there have been no restrictions on migration. Theoretical predictions suggest that income differentials between the Western and Eastern European countries prompt migration, as do the rates of unemployment in both the host and the sending countries. The standard of living, which is influenced by the level of military expenditure in the source country and the host country, is also likely to be of special importance.

The migration model employed to explain migration flows from these countries to Germany is initially estimated using a dynamic panel GMM technique. In the first instance, we find that the income differential between the host and the source country is a factor in triggering migration flows, as are the labour market flows of the host country. The increasing employment rate in the host country as well as a positive difference in per capita income between host and home country increases the long-run stock of migrants.

The results so far are consistent with other modelling work done in the area of migration, the novelty of this paper however is the inclusion of a measure of military expenditure

\footnotetext{
${ }^{22}$ If military expenditure in the source countries changed and if military expenditure did not change.

${ }^{23}$ This includes reducing the potential for the possibility of free riding.
} 
as a proportion of GDP which gives an indication of standard of living, in the migration model. We find that standard of living in the source and the host country is significant in the decision to migrate. More specifically, we show that to the extent that military expenditure affects the standard of living as measured by the proportion of military expenditure to GDP influences migration. More generally, the positive relationship between the standard of living measure and migration implies that countries with higher military expenditure such as Turkey are more likely to see higher migration rates. In other words, living standards (as influenced by the expenditure on national military defence) possess the lion's share in the decision to migrate. Potential migrants are more willing to move as living standards in the source country worsen, which is reflected in the level of real wage (GDP per capita) and the standard of living measure of miliary expenditure and a proportion of that nations' GDP.

Military expenditure is a proxy for potential conflict which implies an incentive for migration to where less conflict is likely. However, our results suggest that accession countries need to have the incentive to reduce their national levels of military expenditure despite the traditional territorial fears. The reduction of military expenditure of Bulgaria and Romania for example would all but eliminate the migrant stock as the standard of living would on average improve by spending the money in other areas to help economic growth.

As to candidate countries Croatia, Macedonia and Turkey a reduction in military expenditure would not wipe out migrant stocks, due in part to the fear of conflict in these countries and the regions and therefore the perceived prospects for a better life in Germany. Therefore steps need to be taken to control the migration flows in the short run as and when they join the EU. This advise has been given previously in the literature in other contexts. Bauer and Zimmermann, 1999 suggest that the anticipation that migrants will move from the accession candidate countries towards the western economies, provides the opportunity for the imposition of a temporary restriction of migration flows in terms of a Common EU migration policy. It is obvious that the European governments have an incentive to impose a temporary, selective immigration policy (such as an auction system or bilateral agreements) towards the candidate countries . However, Boeri and Brucker, (2001) advise that migration flows be kept under control for a transitional pe- 
riod. In other words, the western countries could open gradually, but immediately, their labour markets to migrants from the accession candidates. After a decrease in military expenditure is considered the overall stock of migrants comes from four countries that all have heightened prospects for conflict. Therefore it is likely that a reduction in national military expenditure prompted by confidence in the EU protection measures, will lead to a reduction in the migration stock of most countries we considered.

\section{References}

[1] Arellano M. and Bond S.R. (1991), 'Some Tests of Specification for Panel Data: Monte Carlo Evidence and an Application to Employment Equations', Review of Economic Studies, 58, 277-297.

[2] Assembly of WEU, www.assembly-weu.org/en/presentation/historique.php, downloaded 15 July 2006.

[3] Assembly of WEU, www.assembly-weu.org/en/presentation/composition.php downloaded 15 July 2006.

[4] Assembly of WEU, Press Release 10 February 2006 www.assemblyweu.org/en/presse/cp/2006/004.php downloaded 15 July 2006.

[5] Bauer K. T. and Zimmermann F. K. (1999), 'Assessment of Possible Migration Pressure and its Labour Market Impact Following EU Enlargement to Central and Eastern Europe', A study for the Department of Education and Employment, Research Report, 3, IZA.

[6] Boeri T. and Brucker H. (2001), 'Eastern Enlargement and EU-Labour Markets: Perceptions, Challenges and Opportunities', World Economics, 2(1), 49-68.

[7] Brauer J. (2001), 'Military Expenditure, Economic Performance, and Political Economy of Conflict Resolution in Greece and Turkey', College of Business Administration, Augusta State University. 
[8] Brauer J. (2002), 'A Millennial View on Defence and Peace Economics', Special issue of Defence and Peace Economics.

[9] Cuaresma, J.Crespo. and G. Reitschuler (2004) 'A non-linear defence - growth nexus? Evidence from the US economy' Defence and Peace Economics, 15(1), pp 71 - 82.

[10] Coulomb, F. and J. Fontanel (2005)'An Economic Interpretation of French Military Expenditures'Defence and Peace Economics, 16 (4), pp. 297 - 315.

[11] Drinkwater S., Levine P., Lotti E., and Pearlman J. (2002), 'The Economic Impact of Migration: A Survey', Department of Economics, University of Surrey, UK.

[12] Dunne, P., M. Garcia-Alonso, P. Levine and R. Smith (forthcoming) 'Determining the Defence Industrial Base', Defence and Peace Economics.

[13] Dunne, J.P., S. Perlo-Freeman and A. Soydan (2004a)'Military expenditure and debt in small industrialised economies: A panel analysis'Defence and Peace Economics 15 (2), pp $1-17$.

[14] Dunne, J. P., S. Perlo-Freeman and A. Soydan (2004b)'Military expenditure and debt in South America'Defence and Peace Economics 15 (2), pp 1 - 20.

[15] Dunne, J. P, R. Smith, D. Willenbockel (2005) 'Models of Military Expenditure and Growth: A critical review' Defence and Peace Economics 16(6), pp. 449 - 461.

[16] Hatton J. T. (1995), 'A model of UK emigration, 1870-1913', Review of Economics and Statistics, 77(3), 407-15.

[17] International Labour Organization, LABORSTA, http://laborsta.ilo.org/.

[18] Ihori, T. (2004), 'Arms race and economic growth'Defence and Peace Economics 15 (1), pp $27-38$.

[19] Karagol, E. and S. Palaz (2004)'Does defence expenditure deter economic growth in Turkey? A cointegration analysis' Defence and Peace Economics, 15(3), pp 289 - 298.

[20] Karagol, E. (2005), 'Defence Expenditures and external debt in Turkey' Defence and Peace Economics 16(2), pp 117 - 125. 
[21] Karagol, E. (2006), 'The relationship between external debt, defence expenditures and GNP revisited: The case of Turkey' Defence and Peace Economics 17 (1), pp 47 $-57$.

[22] Kollias, C., C. Naxakisb and L. Zarangasb (2004),'Defence Spending and Growth in Cyprus: A Causal Analysis' Defence and Peace Economics, 15 (3) pp. 299 - 307.

[23] Lee, C-C. and C-P. Chang (2006), 'The Long-run relationship between defence expenditures and GDP in Taiwan' Defence and Peace Economics 17(4), pp 361 - 385.

[24] McCormick B., Hanson G., and Boeri T. (2002), 'Immigration Policy and the Welfare System', The William Davidson Institute at the University of Michigan Business School, Oxford University Press Inc., New York.

[25] Migration Information Source, Global Data Center, http://www.migrationinformation.org/.

[26] NATO (2001), NATO Handbook, www.nato.int/docu/handbook/2001/hb0403.htm

[27] Sargan, J. (1958), 'The Estimation of Economic Relationships using Instrumental Variables', Econometrica, 26, 393-415.

[28] Stockholm International Peace Research Institute, http://www.sipri.org/.

[29] United Nations, National Accounts Main Aggregates Database, http://www.un.org/.

[30] Yildirim, J., S. Sezgin and N. Ocal(2005) 'Military Expenditure and Economic Growth in Middle Eastern Countries: A Panel Data Analysis', Defence and Peace Economics, 16 (4), pp. $283-295$.

[31] Yildirim, J., S. and N. Ocal (2006), 'Arms Race and Economic Growth: The Case of India and Pakistan' Defence and Peace Economics, 17 (1), pp. 37 - 45. 


\begin{tabular}{||c|c|c|c|c||}
\hline Country & Unemployment Rates & $\begin{array}{c}\text { GDP Per } \\
\text { Capita }\end{array}$ & $\frac{\text { Migrants Stock }}{\text { Population }}$ & $\frac{M E}{\text { GDP }}$ \\
\hline Bulgaria & 15.31 & 1,562 & 0.44 & 2.42 \\
\hline Croatia & 13.13 & 4,422 & 4.62 & 5 \\
\hline Cyprus & 4.47 & 12,220 & 0.12 & 2.63 \\
\hline Czech Republic & 6.52 & 5,867 & 0.21 & 1.76 \\
\hline Estonia & 10.97 & 3,930 & 0.24 & 1.24 \\
\hline Hungary & 7.69 & 4,804 & 0.53 & 1.66 \\
\hline Latvia & 14.80 & 2,899 & 0.29 & 0.89 \\
\hline Lithuania & 15.38 & 2,967 & 0.23 & 1.14 \\
\hline TFYR Macedonia & 31.20 & 1,923 & 2.35 & 2.93 \\
\hline Malta & 6.70 & 9,742 & 0.08 & 0.77 \\
\hline Poland & 14.43 & 4,274 & 0.75 & 1.92 \\
\hline Romania & 6.99 & 1,722 & 0.42 & 2.65 \\
\hline Serbia and Montenegro & 13.39 & 1,353 & 6.64 & - \\
\hline Slovakia & 15.15 & 3,928 & 0.22 & 2.18 \\
\hline Slovenia & 6.99 & 10,337 & 0.94 & 1.44 \\
\hline Turkey & 7.55 & 2,738 & 3 & 4.6 \\
\hline Total CEECs & 11.34 & 4,668 & 1.32 & 2.21 \\
\hline Germany & 8.96 & 26,268 & - & 1.52 \\
\hline
\end{tabular}

Notes: Unemployment rates, stock of migrants over total population, and military expenditure over

GDP appear in percentage terms, while GDP per capita is expressed in current US dollars.

Table 1: Descriptive Statistics - Mean values for the main aggregates by country 


\begin{tabular}{|c|c|c|c|c|}
\hline $\begin{array}{c}\text { Dependent } \\
\text { variable: } \Delta S M_{i, t}\end{array}$ & $\begin{array}{l}\text { Regression } \\
\text { (1) }\end{array}$ & $\begin{array}{c}\text { Regression } \\
\text { (2) }\end{array}$ & $\begin{array}{c}\text { Regression } \\
\text { (3) }\end{array}$ & $\begin{array}{c}\text { Regression } \\
\text { (4) }\end{array}$ \\
\hline Regressor & \multicolumn{4}{|c|}{$\begin{array}{c}\text { Estimated Coefficients } \\
\text { (z-scores) }\end{array}$} \\
\hline$\Delta S M_{i, t-1}$ & $\begin{array}{l}-0.001^{* * * *} \\
(-2.75)\end{array}$ & $\begin{array}{l}-0.001^{*} \\
(-1.81) \\
\end{array}$ & $\begin{array}{c}-0.001^{* * *} \\
(-2.84)\end{array}$ & $\begin{array}{c}-0.0003 \\
(-0.36) \\
\end{array}$ \\
\hline$\Delta \ln \left(E_{F}\right)_{i, t}$ & $\begin{array}{l}0.02^{* * * *} \\
(3.20)\end{array}$ & $\begin{array}{l}0.06^{* * * *} \\
(3.18)\end{array}$ & $\begin{array}{l}0.02^{*} \\
(1.72)\end{array}$ & $\begin{array}{l}0.07^{* * *} \\
(4.92)\end{array}$ \\
\hline$\Delta \ln \left(E_{H}\right)_{i, t}$ & $\begin{array}{l}-0.02^{* * *} \\
(-3.11)\end{array}$ & $\begin{array}{l}-0.01^{*} \\
(-1.66)\end{array}$ & $\begin{array}{l}-0.02^{* * *} \\
(-2.75)\end{array}$ & $\begin{array}{l}-0.02^{* * *} \\
(-2.77)\end{array}$ \\
\hline$\Delta \ln \left(\frac{Y_{F}}{Y_{H}}\right)_{i, t-1}$ & $\begin{array}{l}0.001^{*} \\
(1.68)\end{array}$ & $\begin{array}{c}0.002^{* * *} \\
(3.08)\end{array}$ & $\begin{array}{l}0.001^{*} \\
(1.89)\end{array}$ & $\begin{array}{l}0.002^{* * *} \\
(3.19)\end{array}$ \\
\hline $\ln \left(E_{F}\right)_{i, t-1}$ & $\begin{array}{l}0.01^{* * *} \\
(5.71)\end{array}$ & $\begin{array}{l}0.01^{* * *} \\
(4.76)\end{array}$ & $\begin{array}{c}0.009^{* * *} \\
(2.91)\end{array}$ & $\begin{array}{l}0.02^{* * *} \\
(4.20)\end{array}$ \\
\hline $\ln \left(E_{H}\right)_{i, t-1}$ & $\begin{array}{l}-0.006^{* *} \\
(-2.51) \\
\end{array}$ & $\begin{array}{c}0.0005 \\
(0.20) \\
\end{array}$ & $\begin{array}{l}-0.006 \\
(-2.28) \\
\end{array}$ & $\begin{array}{l}-0.001 \\
(-0.77) \\
\end{array}$ \\
\hline $\ln \left(\frac{Y_{F}}{Y_{H}}\right)_{i, t-1}$ & $\begin{array}{c}0.0006^{* * *} \\
(2.75)\end{array}$ & $\begin{array}{c}0.002^{* * *} \\
(3.80)\end{array}$ & $\begin{array}{c}0.0004 \\
(1.45)\end{array}$ & $\begin{array}{l}0.002^{* * *} \\
(3.56)\end{array}$ \\
\hline$\left(\frac{M E_{H}}{G D P_{H}}\right)_{i, t-1}$ & - & $\begin{array}{l}0.02^{* * *} \\
(3.05)\end{array}$ & - & $\begin{array}{l}0.02^{* * * *} \\
(3.17)\end{array}$ \\
\hline$\left(\frac{M E_{F}}{G D P_{F}}\right)_{i, t-1}$ & - & - & $\begin{array}{c}0.24 \\
(1.13)\end{array}$ & $\begin{array}{l}-0.70^{* *} \\
(-2.08)\end{array}$ \\
\hline Observations & 78 & 72 & 78 & 72 \\
\hline \multicolumn{5}{|c|}{ Diagnostics } \\
\hline$m_{1}$ & -1.14 & -0.65 & -1.16 & -0.65 \\
\hline$m_{2}$ & 0.29 & 0.96 & 0.44 & 1.27 \\
\hline Sargan & $\begin{array}{c}9.56 \\
\text { (p-value:0.97) } \\
\end{array}$ & $\begin{array}{c}9.79 \\
\text { (p-value:0.97) } \\
\end{array}$ & $\begin{array}{c}9.73 \\
\text { (p-value:0.97) } \\
\end{array}$ & $\begin{array}{c}6.12 \\
\text { (p-value:0.99) }\end{array}$ \\
\hline \multicolumn{5}{|c|}{$\begin{array}{c}\text { Hypothesis Testing } \\
\end{array}$} \\
\hline$H_{0}: \delta_{8}=0$ & - & $\begin{array}{c}x^{2}=9.31^{* * *} \\
\text { (p-value: } 0.00)\end{array}$ & - & $\begin{array}{c}x^{2}=10.04^{* * *} \\
\text { (p-value:0.00) }\end{array}$ \\
\hline$H_{0}: \delta_{9}=0$ & - & - & $\begin{array}{c}x^{2}=1.29 \\
(p-v a l u e: 0.25)\end{array}$ & $\begin{array}{c}x^{2}=4.34^{* *} \\
(\mathrm{p} \text {-value:0.03) }\end{array}$ \\
\hline$H_{0}: \delta_{8}=\delta_{9}=0$ & - & - & 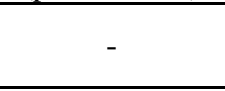 & $\begin{array}{c}x^{2}=10.38^{* * *} \\
\text { (p-value:0.00) }\end{array}$ \\
\hline$H_{0}: \delta_{8}=\delta_{9}$ & - & - & - & $\begin{array}{c}x^{2}=4.55^{* *} \\
\text { (p-value:0.03) }\end{array}$ \\
\hline
\end{tabular}

Notes: Numbers in parentheses denote z-scores, $m_{1}$ and $m_{2}$ are residual first and second order serial correlation tests, while Sargan stands for the over-identifying restrictions test. One, two, three asterisks denote significance at the 10,5 , and 1 percent level respectively.

Table 2: Estimation Results 


\begin{tabular}{|c|c|}
\hline Hypothesis Testing & $\begin{array}{c}\text { Wilcoxon Test } \\
\text { (p-values) }\end{array}$ \\
\hline$H_{0}:$ per cap $G D P_{F}=$ per cap $G D P_{H}$ & -9.81 \\
& $(0.00)$ \\
\hline$H_{0}:$ Unempl $_{F}=$ Unempl $_{H}$ & 4.36 \\
$H_{0}: M E_{F}=M E_{H}$ & $0.00)$ \\
\hline
\end{tabular}

Notes: The null hypothesis is that, for every given pair, the associated factors between the foreign and the home countries are of equal impact.

Table 3: Wilcoxon Tests - Tests for the equal impact of the factors determining migration 